\title{
Species composition and population density of Phytoplankton of Great Bitter Lake, Suez Canal, Egypt.
}

\author{
Mona M. Gab Allah \\ Botany Department, Faculty of Science, \\ Ismailia, Suez Canal University.
}

Gab Allah M. M. 2001. Species composition and population density of Phytoplankton of Great Bitter Lake, Suez Canal, Egypt. . Taeckholmia 21(2): 187-203.

\begin{abstract}
The structure and dynamic of phytoplankton assemblages in Great Bitter Lakes were studied seasonally during the period from May 1999 to February 2000. Population density varied between $112198 X 10^{3}$ cells. $1^{-1}$ in spring and $2382 \times 10^{6}$ cells. $1^{-1}$ in winter. In terms of cell number, Bacillariophyceae was the most important group (mean annual percentage contribution was 67\%), which remained dominant throughout the study period. Cyanophyceae ranked the second abundant group (14\%) dominated in autumn and winter. The contribution of Dinophyceae and Chlorophyceae were 8.6 and $7.3 \%$ respectively. The other classes contributed with very low share of the total phytoplankton. The relationship between phytoplankton composition and physico-chemical variables was studied. CCA analysis indicated that water salinity, and temperature are the most important factors affecting phytoplankton distribution. The trophic status index indicated that the lake ranked between mesotrophic and moderately eutrophic. In winter, the lake was under blooming due to the luxuriance growth of Nitzschia pseudo delicatissima Hasle. and Phormidium sp. The impact of pollution was significantly effective in the western side of the lake compared to the eastern one.
\end{abstract}

Key words: Phytoplankton, Bitter Lakes, trophic status, C.C.A., ecology, taxonomy.

\section{Introduction}

The Great Bitter Lake is the largest water body in the Suez Canal. It is the oldest in its formation in this region, which has specific conditions and plays an important role in the migration of species via Suez Canal between the northern region of Red Sea and the eastern one of Mediterranean Sea. Because of its specific hydrographical and morphological characters, it may be considered, in some cases, as a barrier in the migration of some planktonic species.

With the exception of Ghazzawi (1939) few researchers has been touched upon the area (Halim, 1963 \& 1965, Kimor, 1972; Dowider, 1976; and Heimdal et al., 1977) and the record of phytoplankton studies was based on short collecting periods. The only information available consisted of small quantitative and qualitative scale of phytoplankton (Madkour, 1989, El-Sherif \& Ibrahim1993).

Information about the lake now is desirable, since extensive human settlement has taken place there in the last years, leading to a rapid deterioration of the coastal waters where domestic and industrial effluents are continuously discharged and the lake is subjected to continuous drastic changes as a result of urban and tourist projects as well as the operation of widening and dredging the Canal. This, of course, would affect to some extent, the ecological and biological conditions prevailing in the lake. Such changes will be manifested in the flourishing or avoidance of some organisms including 
phytoplanktons. Accordingly, the present paper verified the physical and chemical properties of the lake water, species composition and the seasonal fluctuations of the different algal groups. Also, this study is an attempt to give some ecological information upon the trophic status of water quality in the Great Bitter Lakes.

\section{Study area}

The Great Bitter Lakes is one of the Suez Canal Lakes. It lies at $30^{\circ} 14^{`}-30^{\circ} 25^{`}$ latitude and at $32^{\circ} 17^{\circ}-32^{\circ} 30^{\prime}$ longitude. It has a maximum length of about $63 \mathrm{Km}$, a maximum width of about $13 \mathrm{Km}$ and a maximum depth of about $20 \mathrm{~m}$. The basin of the Bitter Lakes was a Sabkha-like salt swamp, into which very high tides of the Gulf of Suez were flooded. The shores of the lake are generally sandy with some rocky beach area alongside. The current in the lake is likely to be the northward direction throughout the most of the year. This may be due to the higher sea level at Suez than at Port Said, but it is reversed from July-October (Dowidar, 1974) due to the higher sea level at the Mediterranean Sea at the time than the sea level at the Gulf of Suez.

\section{Materials \& Methods}

Sampling locations are presented in Fig. (1). Sampling started in May, 1999 and was carried out seasonally until February 2000. Samples (2 L) were collected from 6 stations by water sampler. Water temperature was recorded using a standard thermometer (accurately $0.1{ }^{\circ} \mathrm{C}$ ) and digital $\mathrm{pH}$ meter (Cole parmer USA) was used to measure $\mathrm{pH}$. Dissolved Oxygen (DO) was determined by oxygen meter (Cole Parmer USA). Transparency of the water was recorded using a Secchi disc. Chemical analysis of the water were carried out after filtration throughout Whatman $(\mathrm{GF} / \mathrm{C})$ filters and were determined according to APHA methods (1992). Chlorophyll a was determined according to Strickland and Pearson 1963.

\section{Phytoplankton sampling}

The preserved samples with Lugol's solution were concentrated to $100 \mathrm{ml}$ by decanting. Phytoplankton cells in the concentrated samples were counted with inverted microscope at $16 \times 20$ and 16 X 40 magnification and were expressed as units per ml (filaments, colonies or single cells). Keys and reference books used for identification were VanHeurck (1896), Hustedt (1930 - 1937), Perscott (1978), Desikachary (1959), Hendey (1964), and Tomas (1997).

\section{Data Analysis}

Principle Component Analysis on a correlation matrix of the standardized physical and chemical variable was used to investigate the seasonal influence of these variables on algal groups. This CCA was performed by using MVSP Package program ver 3.1. 


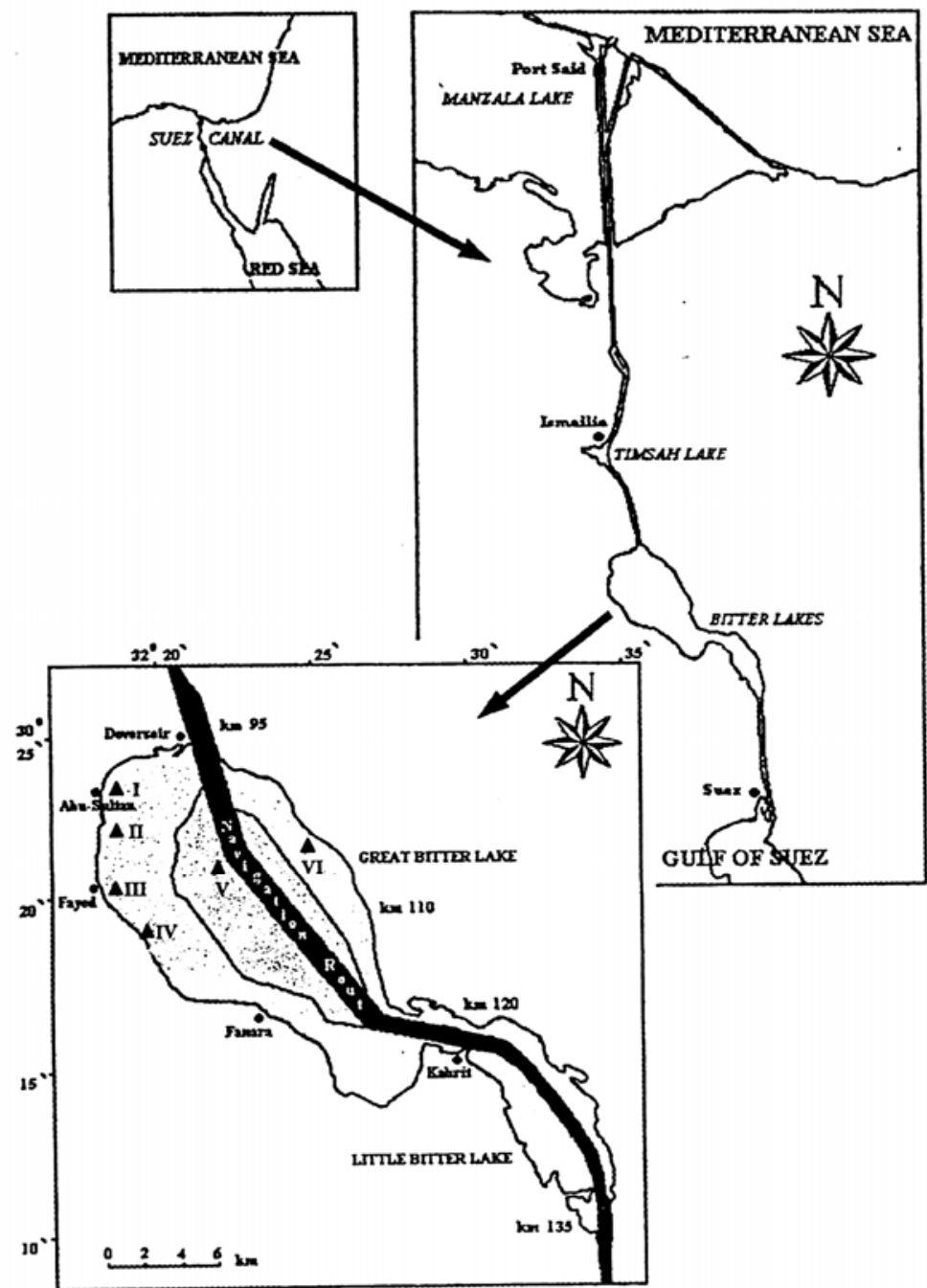

Figure 1. The location of the study sites in Great Bitter Lake (Suez Canal). The triangles indicate the locations of the respective stations. St. I. Inlet of Electric Power Plant (E. P. P.), St. II. Out let of E.P.P, St. III. Palma beach, St. IV. Malaria drain, St. V. Main channel, St. VI. The eastern side.

\section{Results and Discussion}

\section{Environmental parameters}

The seasonal variation of some physico chemical parameters are represented in Figs. (2\&3). The minimum \& maximum values of them are present in Table (1). The lowest water temperature registered in winter $\left(16^{\circ} \mathrm{C}\right)$ and the highest was $\left(29^{\circ} \mathrm{C}\right)$ detected in summer at most sites except at station II (The outlet of E.P.P), the range of its water 
temperature was above the ambient one by $20-21^{\circ} \mathrm{C}$. $\mathrm{pH}$ values recorded in the lake fall in the alkaline range $(7.3-8.5)$. Depth ranged from 1.5 and $30.8 \mathrm{~m}$. Secchi disc readings ranged from 0.25 to $2.81 \mathrm{~m}$. The euphotic zone does not extend to the bottom in the main channel and the eastern regions. This may be due to the movements of the ships in this area which cause the water to be turbid. In other stations in the western side, the photic zone may extend to the bottom. Dissolved oxygen in the surface water fluctuated between 3.4 at St II and $10.2 \mathrm{mg} \mathrm{O}_{2} \mathrm{l}^{-1}$ at St IV. Its lowest values recorded in summer and the highest during winter. Conductivity varied between 42.3 at St III and 107.8 mmohscm $^{-1}$ at St II. Its highest values recorded in summer and the lowest in winter. Salinity reached its maximum value $(45.7 \%)$ in summer and its minimum value of $32.8 \%$ in winter. Their lowest readings (32.8-33.2\%) registered at stations III \& IV at the western bank of the lake due to the fresh water discharge from Malaria agricultural drainage and the village tours settled at these stations, while its highest readings $(45.2-45.7 \%)$ occurred in St. II and eastern side. Miller \& Munn (1974) stated that salinity will be always high in Great Bitter Lakes often complete dissolution of the salt bed, due to the high evaporation rate. Madkour (1989) pointed out that, the salinity didn't fall below 40\%o during her investigation period. However, the recent uncontrolled development in and around the lake and the discharge of Malaria drainage increases the fresh water into the lake and consequently the salinity may be reduced. $\mathrm{NH}_{4}-\mathrm{H}$ values in all sampling sites varied between 30.4 at St II and $253 \mu \mathrm{g} \mathrm{l}^{-1}$ at St IV. It had higher values in autumn and winter. The results of ammonia in our study was high as compared to that of Madkour (1989) i.e. it didn't exceed $0.02 \mu \mathrm{g} \mathrm{l}^{-1}$ during her investigation period and consequently she considered the lake as an oligotrophic. $\mathrm{NO}_{3}-\mathrm{N}$ concentrations ranged between 6.3 at St II and 190 $\mu \mathrm{g} \mathrm{I}^{-1}$ at St IV. It exhibited high values during spring and winter, while the lowest one during summer. The source of high concentration is due to organic matter supply carried with fresh water from domestic sewage from the tourism villages on the western side of the lake. $\mathrm{NO}_{2}-\mathrm{N}$ concentrations remained below $35 \mu \mathrm{g} \mathrm{l} \mathrm{I}^{-1} . \mathrm{PO}_{4}-\mathrm{P}$, which forms about $5 \%$ of the total phosphorus in a lake (Wetzel, 1983), and is the most available form for phytoplankton. $\mathrm{PO}_{4}-\mathrm{P}$ levels reached its maximum values $\left(55.7 \mu \mathrm{g} \mathrm{l}^{-1}\right)$ at $\mathrm{St} \mathrm{IV}$, and a minimum of $6.4 \mu \mathrm{g}^{-1}$ at St I. Its higher values were observed during winter and the lower during autumn Fig. (3) $\mathrm{PO}_{4}-\mathrm{P}$ levels as compared with Madkour (1989), doubled in the past decades. This is could be attributed to eutrophication caused by waste $\&$ input of drain terminating in the lake along the western side. $\mathrm{SiO}_{3}$-Si values fluctuated between 2.7 at St I and $6.6 \mathrm{mg} \mathrm{l}^{-1}$ at St V. Its highest values occurred in spring and the lowest in autumn. The importance of the element lies in its significance for the construction of the cell wall of diatoms. This element is not a limiting factor for diatoms in the lake. Willem (1991) reported dissolved silica content between 0.03 and $0.20 \mathrm{mg} \mathrm{l}^{-1}$ as limiting level for diatom growth.

The N:P ratio in the water is an important variable since it can denote which of these nutrients appears to be in excess for phytoplankton growth. Redfield (1958) found an average ratio of 15 in oceans, a value that also applies to freshwater. In Great Bitter Lakes, the ratio ranged between 2.8 and 22. The lowest value occurred at the outlet of E.P.P. and IV (Malaria). This could be attributed to eutrophication caused by wastewater of heated water and domestic input into the lake. In this connection Knuuttila et al. (1994), stated this ratio is lower in eutrophic than oligotrophic lakes. 
Species composition and population density of phytoplankton of Great Bitter Lake, Suez Canal, Egypt.
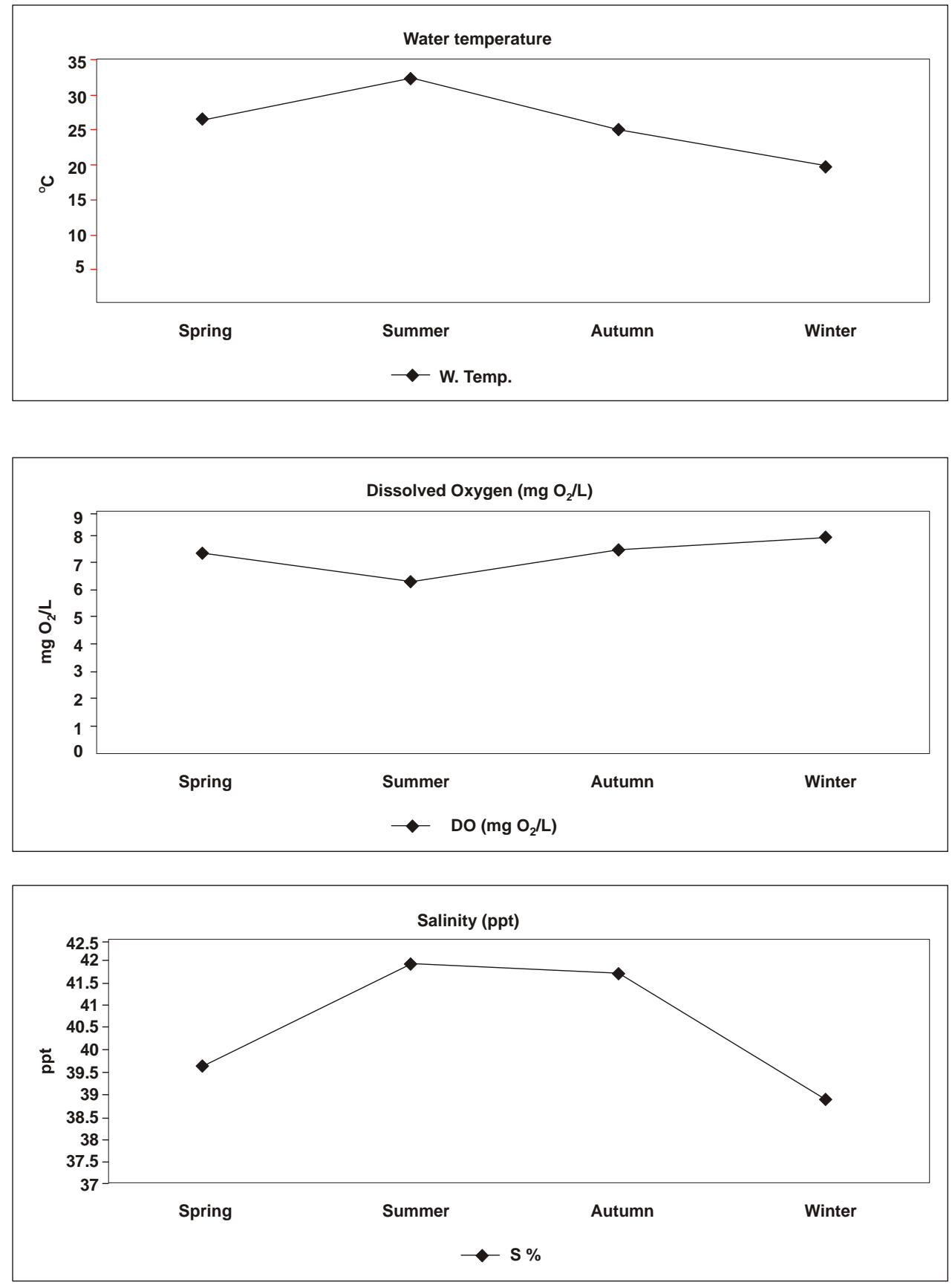

Figure 2. Seasonal variations of some physico-chemical parameters 
M. M. Gab Allah
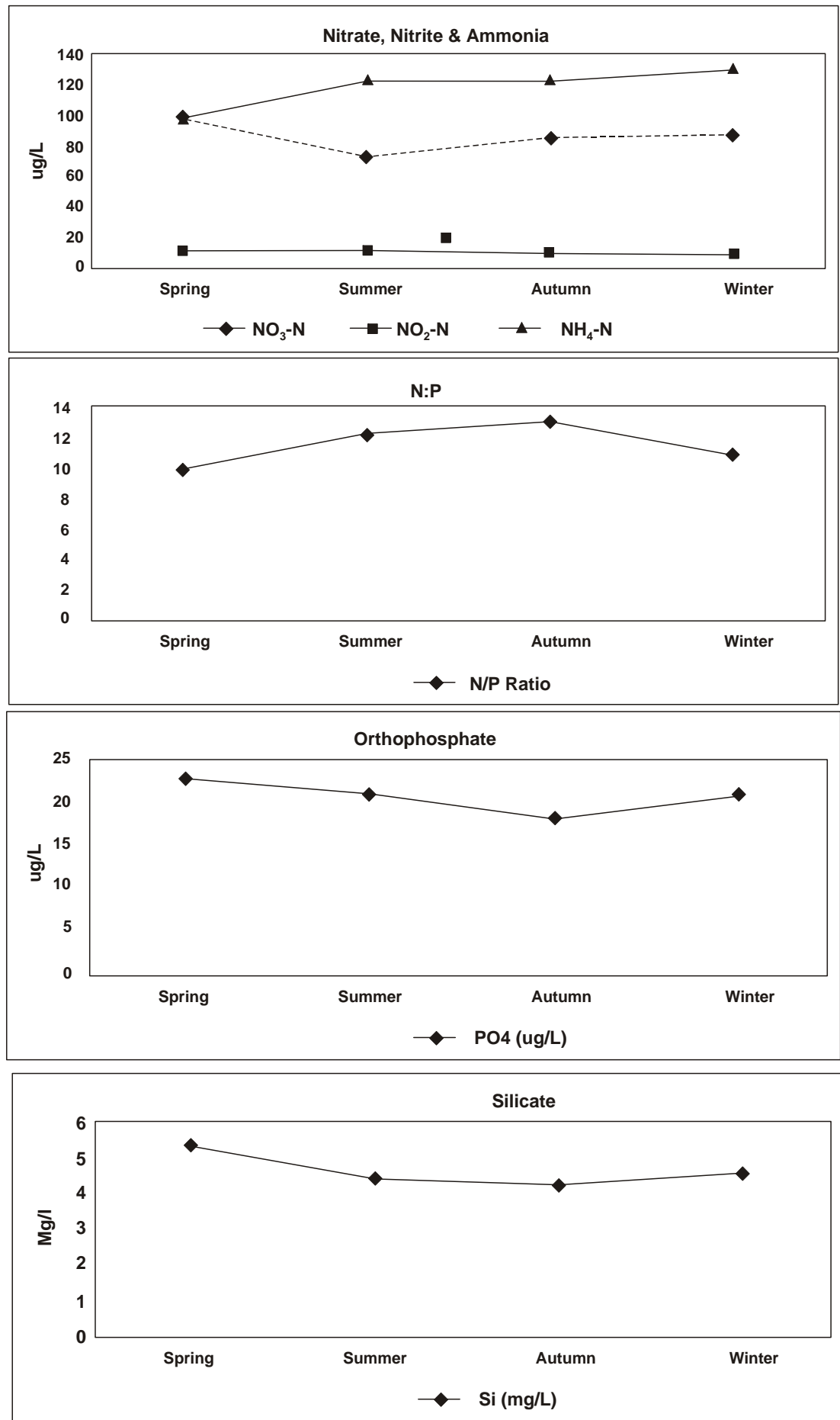

Figure 3. Seasonal variations of some nutrient salts 
Species composition and population density of phytoplankton of Great Bitter Lake, Suez Canal, Egypt.

Table 1. Range of change in some physio-chemical characters of water of Great Bitter Lake at different stations during the period May 1999-February 2000.

\begin{tabular}{|c|c|c|c|c|c|c|c|c|c|c|c|c|}
\hline \multirow{2}{*}{$\begin{array}{l}\text { Parameters, } \\
\text { unites }\end{array}$} & \multicolumn{2}{|c|}{ St I } & \multicolumn{2}{|c|}{ St II } & \multicolumn{2}{|c|}{ St III } & \multicolumn{2}{|c|}{ St IV } & \multicolumn{2}{|c|}{ St V } & \multicolumn{2}{|c|}{ St VI } \\
\hline & Min & $\operatorname{Max}$ & Min & Max & Min & Max & Min & Max & Min & Max & Min & Max \\
\hline Temperature ${ }^{\circ} \mathrm{C}$ & 16 & 28 & 36 & 50 & 17 & 28 & 16.5 & 28 & 17 & 29 & 18 & 29 \\
\hline $\mathrm{pH}$ & 7.4 & 7.6 & 7.3 & 7.8 & 7.4 & 7.9 & 7.4 & 7.9 & 8.2 & 8.5 & 7.4 & 7.8 \\
\hline Secchi disk $\mathrm{m}$ & 0.25 & 0.35 & 0.3 & 0.4 & 2 & 2.1 & 1.3 & 1.5 & 1.4 & 2.8 & 1.2 & 2 \\
\hline Depth m & 10 & 12 & 1.5 & 1.75 & 6.5 & 7 & 3.6 & 4.5 & 25.6 & 30.8 & 3.2 & 25 \\
\hline Conductivity $\mathrm{m}$ & 54.7 & 71.5 & 78 & 107.8 & 48.5 & 57 & 42.5 & 51.5 & 52.5 & 69 & 51 & 64 \\
\hline $\begin{array}{l}\text { Dissolved } \\
\text { Oxygen } \mathrm{mgO}_{2} \mathrm{l}^{-1}\end{array}$ & 7.2 & 8 & 3.4 & 6.2 & 7.2 & 7.9 & 6.3 & 10.2 & 7.4 & 8.2 & 7.3 & 8.2 \\
\hline Salinity $\%$ (ppt) & 42.6 & 44.8 & 42.4 & 45.2 & 32.8 & 36 & 33.2 & 35.8 & 41.8 & 43.8 & 40.6 & 45.7 \\
\hline Nitrate $\mu \mathrm{gl}^{-1}$ & 42.6 & 70.8 & 6.3 & 15.4 & 65.5 & 12.5 & 130 & 150 & 65.6 & 111 & 65 & 148 \\
\hline Nitrite $\mu \mathrm{gl}^{-1}$ & 2.7 & 8.2 & 0.0 & 1.4 & 15.4 & 21.4 & 25.6 & 35 & 20.5 & 29.6 & 10 & 18 \\
\hline Ammonia $\mu \mathrm{gl}^{-1}$ & 67.6 & 115.6 & 30.4 & 90.6 & 75 & 121 & 178 & 253 & 114 & 153 & 92 & 150 \\
\hline $\mathrm{PO}_{4}-\mathrm{p} \mu \mathrm{gl}^{-1}$ & 6.4 & 12.2 & 13.4 & 17.8 & 15.3 & 20.4 & 30.8 & 55.7 & 20.5 & 29.6 & 10.8 & 18 \\
\hline Silicate $\mathrm{mgl}^{-1}$ & 2.7 & 5.6 & 4.6 & 5.8 & 4.8 & 5.2 & 3.4 & 4.8 & 4.3 & 6.6 & 4.3 & 5.3 \\
\hline $\begin{array}{l}\text { Clorophyll a } \\
{\mu \mathrm{gl}^{-1}}^{-1}\end{array}$ & 5.8 & 25.3 & 2.5 & 15.2 & 0.3 & 8.5 & 5.2 & 9.5 & 4.8 & 10.4 & 3.3 & 8.9 \\
\hline Nip ratio & 12.9 & 22 & 2.8 & 6.6 & 10.4 & 12.8 & 7.2 & 12.5 & 3.5 & 11.4 & 13.7 & 20.8 \\
\hline
\end{tabular}

\section{CCA Ordination}

Figures $4 \& 5$ presents the graphic representation of the Canonical Correspondence Analysis for axis 1 and 2. Community structure and distribution along the gradient of 11 variables are clear. Fig. 4 indicates that PO4 and NO3 are positively correlated with axis 1 and $\mathrm{S} \%, \mathrm{EC}$ and water temperature are negatively correlated with algal groups. Fig. 5 indicates that $\mathrm{PO}_{4}-\mathrm{P}, \mathrm{Si}_{-} \mathrm{SO}_{3}$ are negatively correlated with the leading species of phytoplankton while $\mathrm{N}: \mathrm{P}, \mathrm{S} \% 0$ and $\mathrm{NO}_{3}$ are positively correlated.

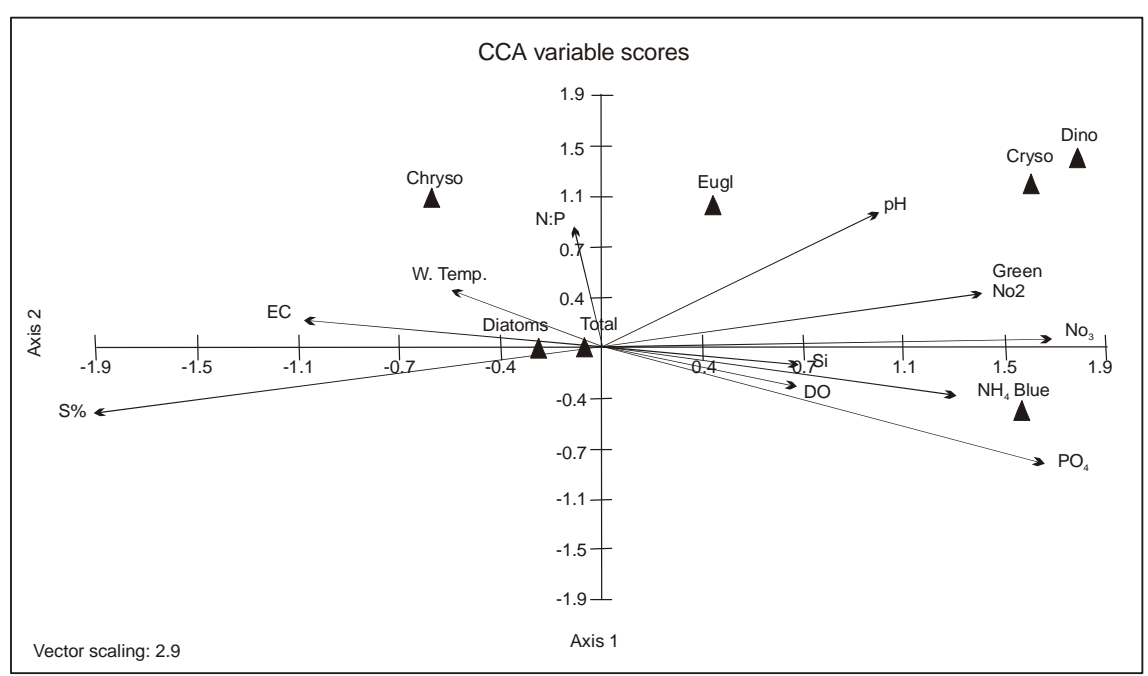

Figure 4: CCA ordination of some environmental variables represented by arrows and the algal represented by triangle legand. Dino.: Dinophyceae, Blue: Cyanophyceae, Eugl.: Euglenophyceae, Diatoms: Bacillariophyceae, Crypt.: Cryptophyceae, Cryso: Crysophyceae, Green: Chlorophyceae, Total: Total phytoplankton 


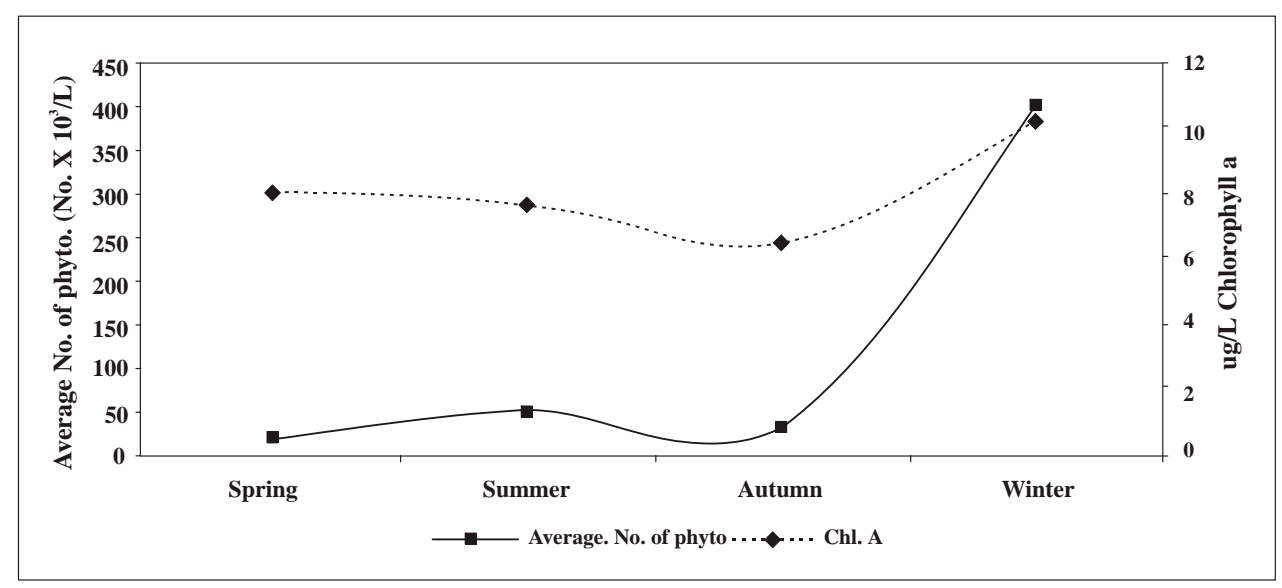

Figure 5: Relationship between average number of Phytoplankton density \& Chlorophyll a during the period of investigation

\section{Biological Parameters}

\section{Chlorophyll a}

Phytoplankton biomass that is represented by Chlorophyll a varied between 0.3 and 15.2 $\mu \mathrm{gl}-1$. Its concentration is reflecting the number of individuals. Its value in the past decads (Madkour, 1989), ranged between 0.29 and $1.5 \mu \mathrm{gl}-1$ and the cause of increase off now due to the general increasing of nutrients. Chlorophyll a values coincided with the total number of phytoplankton cells (Fig. 6).

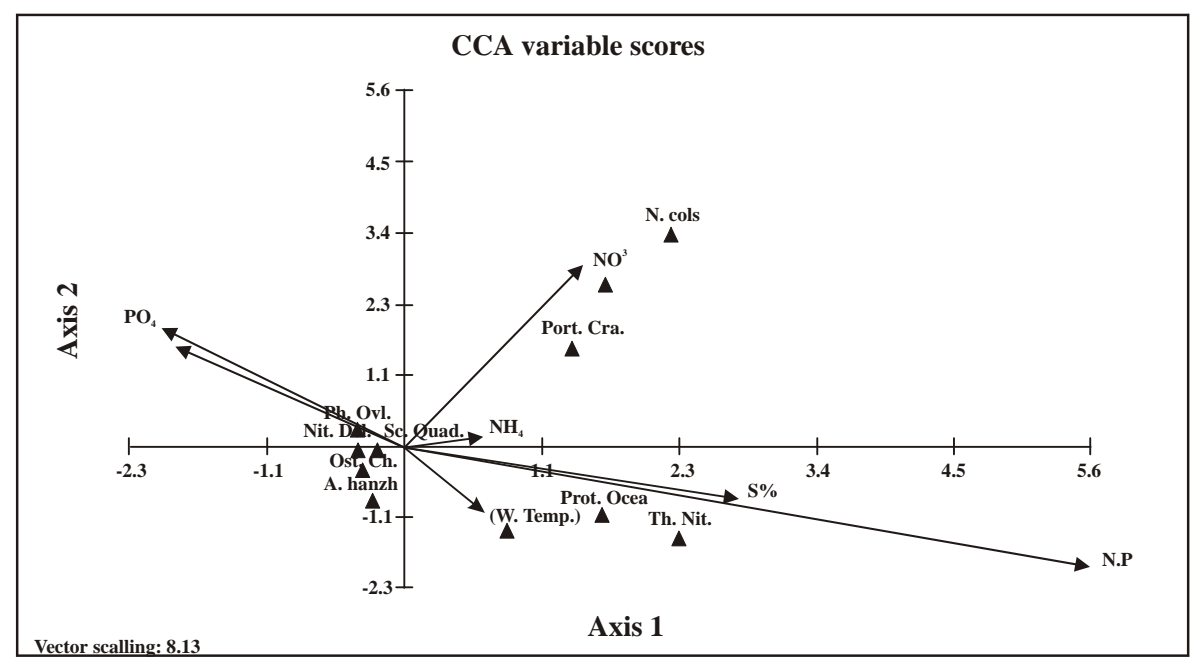

Figure 6: CCA ordination of some environmental variables represented by arrows and leading species of phytoplankton represented by triangle. N. cols.: Nitzschia closterium, Prot. Ocea: Protodintium oceanicum, Ph. Ovl.: Phormidium, A. hanzh : Actinastrium hanzchii, Nit. Del.: Nitzschia delictissima, Th. Nit.: Thalassionema nitzschoidae, Prot. Cra.: Protodintium crassus, Ost. Ch.: Oscillatoria chalybae, Sc. Quad.: Scendesmus quadricauda. 
Species composition and population density of phytoplankton of Great Bitter Lake, Suez Canal, Egypt.

\section{Species Composition and Population Density}

A total of 171 taxa have been identified (Table 2). Most of them belong to Bacillariophyceae (88), Dinophyceae (29), Chlorophyceae (26), Cyanophyceae (24), Euglenophyceae (2), Chrysophyceae (1) and Cryptophyceae (1); (Table 3). The seasonal variation of these groups presented in (Fig. 7).

The maximum occurrence of the total phytoplankton density $\left(2810 \times 106{\left.\text { cells } 1^{-1}\right)}^{-1}\right.$ was recorded in winter (Fig. 6) and can be attributed to concurrent increase of Bacillariophyceae $(69.7 \%)$ and Cyanophyceae $(27.2 \%)$ which coincided with high concentrations of NH4-N, Po4-P and $\mathrm{NO}_{3}-\mathrm{N}$ and relatively higher values of salinity (32 - $42 \%$ ). The blooming of Bacillariophceae and Cyanophyceae developed when the concentration of $\mathrm{PO}_{4}-\mathrm{P}$ and $\mathrm{NH} 4-\mathrm{N}$ are high and $\mathrm{NO}_{3}-\mathrm{N}$ is comparatively low (Abdul Hussein and Mason, 1985), and according to Greenwald \& Hurburt (1993), stated that the phytoplankton abundance increases as salinity ranges from (17-42 $\mathrm{S} \%$ ). The above statements seem to be in agreement with our results. The total phytoplankton and diatoms were located towards the center of the ordinations, indicating their apparent indifference to the environmental variables and yearround persistence in the lake (Fig. 4).

Bacillarophyceae constituted the dominant algal groups in terms of cell numbers and taxa. This was also recorded by Madkour (1989). The mimimum occurrence of diatom observed during spring (62\%), while the maximum one $(69.7 \%)$ recorded in winter when water temperature was $16.5-18^{\circ} \mathrm{C}, \mathrm{NH}_{4}-\mathrm{N}$, and $\mathrm{NO}_{3}-\mathrm{N}$ were high Fig. (3) when compared to $\mathrm{PO}_{4}-\mathrm{P}$ concentrations. The increase in populations of this group at high nitrogen concentrations and low temperatures agrees with the findings of Tilman et al. (1986), who stated that diatoms are good competitors for phosphorus but weak competitors for nitrogen.

The dominancy of Bacillariophyceae over the other phytoplankton groups was decoumented by Gab Allah (1985 \& 1991) on lake Timsah \& Manzalah, this may be due to their tolerance to salinity.

Among the dominant species of diatoms were Nitzschia closterium (Her.) W. Smith, Thalassionema nitzschoides Grum, and Nitzschia delicatissima Cleve. Their correlations with variables presented in (Fig. 5).

Nitzschia closterium is a marine form and was recorded by (Ezz. EL-Din, 1990 and Shafik et al., 1999) in Bardawil lake. It was common in Great Bitter lakes and its maximum percentage contribution abundance to total diatom $(98.9 \%)$ was observed in spring when $\mathrm{NO}_{3}-\mathrm{N}$. concentrations reached maxima. Due to this it was positively correlated with high values of $\mathrm{NO}_{3}-\mathrm{N}$, and $\mathrm{N}$ :P ratio and negatively correlated with $\mathrm{PO}_{4}-$ $\mathrm{P}$ and $\mathrm{SiO}_{3}$ values. Thalassionema nitzschoides (Grum.) which was recorded by Gab-Alla (1985), in Timsah lake is known as an indicator of high nutrient conditions and tolerates extreme variable conditions (Van Iprene et al., 1993). Its peak $(82.23 \%)$ occurred in summer when water temperature and salinity were high. Consequently it was more positively correlated with high $\mathrm{N}: \mathrm{P}$ ratio, $\mathrm{S} \%$ and low concentration of $\mathrm{PO}_{4}-\mathrm{P}$ and $\mathrm{SiO}_{3}$ values.

Nitzschia pseudo delicatissima Hasle., attained its high contribution abundance to total diatoms $(65.35 \%)$ forming a bloom in winter. It was positively correlated with high values of $\mathrm{PO}_{4}-\mathrm{P}$ and low concentration of $\mathrm{NO}_{3}-\mathrm{N}$. It is geographically widely distributed genus restricted to marine plankton (Tomas, 1997). It is worth mentioning that 
at the time of predomination of this genus, it produces domoic acid (Martin et al., 1990). Domoic acid may be a worldwide threat on temperate coasts.

Table 2. Species composition of phytoplankton in Great Bitter Lake-Suez Canal-Egypt during the study period (May 1999-February 2000).

\section{Bacillariophyceae}

1. Achnanthes exigua var heterovalvata Krasske

2. A. lanceolata (Breb.) Hüst.

3. Amphiprora alata Kütz.

4. A. ornate Bail.

5. A. coffeaeformis Ag

6. A. decussata Grun.

7. A. ovalis var. ovalis Kütz.

8. A. ovalis var. pediculus Kütz.

9. Astrionella formosa Hass.

10. A. glacialis (Japonica) Castr.

11. Aulacoseira granulata var. gnnulata (Ehr.) Sim.

12. A. granulata var. angustissima (O. Mull) Hüst.

13. A. moniliformis (0. Mull) Ag.

14. Bacillaria paxillifer (O.F Mull) Hendey

15. Bidulphia mobiliensis (Bail) Grun. Ex Van Haurk

16. B. tuomeyi Bail.

17. Caloneis permagna (Bail.) $\mathrm{Cl}$.

18. Chaetoceravis debile $\mathrm{Cl}$.

19. C. densum $\mathrm{Cl}$.

20. Cocconies calcare Cl. A. Cl.

21. C. placentula var. rouxii (Brun. Et Herib.) $\mathrm{Cl}$.

22. Cocindiscus asteromphalus Ehr.

23. Cyclotella meneghiniana Kütz.

24. C. ocellata Pant.

25. Cymatopleura elliptica (Breb.) W.Sm.

26. Cymbella parva (W. Sm.) $\mathrm{Cl}$.

27. C. microcephala Grun.

28. Diatoma sp.

29. Diploneis interrupta (Kütz.) Cleve.

30. D. ovalis (Hilse) $\mathrm{Cl}$.

31. D. pillella $(\mathrm{Sch}$.) $\mathrm{Cl}$

32. Ditylum brightwellii (West.) Grun.

33. Eucampia sp.

34. Fragilaria brevistriata Grun.

35. F. construens (Ehr.) Grun.

36. Gomphonema angustatum (Kütz.) Rab.

37. G. parvulum var. parvulum (Kütz.) Grun.

38. Grammatophora marina (Lyngb.) Kütz.

39. Guinardia flaccida (Cast.) Perag.

40. Gyrosigma attenuatum (Kütz.) Rabh.

41. G. balticum (Kütz.) Rabh.

42. Gyrosigma macrum (Wm. Sm.) Cl.

43. Hemiaulus hauckii Grun.

44. Leptocylndrus danicus $\mathrm{Cl}$.
45. L. minimus Grun

46. Licmophora flabellata (Greve.) Agar.

47. Lithodesmium undulatum Ehr.

48. Navicula abrupta Greg.

49. N. cryptocephala Kütz.

50. N. dicephala (Ehr.) W.Sm.

51. N. hungarica Grun.

52. N. pupula var pupula Kütz.

53. N. pygmaea Kütz.

54. N. salinarum Grun.

55. N. viridulla var viridula Kütz.

56. Nitzschia amphibia Grun.

57. N. closterium (Ehr.) W. Sm.

58. N. hungrica Grun.

59. N. palea var. capitata (Kütz.) W. Sm.

60. N. panduriformis Ehr.

61. N. parvula Lewis.

62. N. pseudo-delicatissima Hasle.

63. N. punctata (W. Sm.) Grun.

64. N. sigma (Ehr.) W. Sm.

65. N. sigma var. rigidula Grun.

66. N. sigmoeodea (Ehr.) W. Sm.

67. N. trybionella var. victoriae Grun.

68. Pleurosigma aestusii (Breb ex Kütz.) W. Sm.

69. P. angulatum Hendey.

70. P. elongatum W. Sm.

71. Rhabdonema adriaticum Kütz.

72. Rhizosolenia alata forma gracillima (Cl.) Grun.

73. $R$. clacar-avis Schult.

74. $R$. fragilissisma Berg.

75. R. styliformis Brighwell.

76. Stephanodiscus hanzschii (Grim.)

77. Surirella ovalis var. ovata Kütz.

78. S. robusta Ehr.

79. Synedra acus var. radians Ehr.

80. S. pulchella Kütz.

81. S. ulna var. biceps (Kütz.) Grun.

82. S. ulna var. ulna (Nitzsch) Ehr.

83. Tabellaria var asterion alloides (Roth.) Kütz.

84. Thalassionema nitzschoides Grun.

85. Thalassissira decipiens (Gum.) Gorg

86. Th. excentrica (Ehr.) Cl.

87. Thalassiothrix frauenfeldii Grun.

88. Triceratium reticulatum Ehr. 
Species composition and population density of phytoplankton of Great Bitter Lake, Suez Canal, Egypt.

Table 2. Continued

\begin{tabular}{|c|c|}
\hline Chlorophyceae & 129. Oscillatoria chalybea (Mert) Gom. \\
\hline 89. Actinasrtum hanzschii Lag. & 130. O. geminata f. sulphurea (Stesz.) Elenk. \\
\hline 90. Ankistrodesmus falcatus (Corda) Ralfs & 131. O. limosa Ag. Ex Gom. \\
\hline 91. Chlamydomonas sp. & 132. O. splendida Grev. Ex Gom. \\
\hline 92. Chlorella sp. & 133. O. subtilissima Kütz. \\
\hline 93. Chlorogonium sp. & 134. Phormidium sp. \\
\hline 94. Closteriopsis sp. & 135. Pseudoanabaena limnetica (Lemm.) Kom. \\
\hline 95. Closterium sp. & 136. Spirulina subsalsa Ostred. \\
\hline 96. Coelastrum microporum Naeg. in A.Br. & 137. S. subtilissima (Kütz.) ex. Gom. \\
\hline 97. Crucigenia rectangularis (A.Br) Gay & 138. Symechocystis salina Wisl. \\
\hline 98. C. tetrapedia (Kirch.) W \& G. S. Wes. & 139. S. pervalekii Ercegovic \\
\hline 99. Dictyosphaerium pulchellum Wood & 140. Synechococcus elongatus Nag. \\
\hline \multicolumn{2}{|l|}{ 100. Kirchenerella obesa (W. West.) Schm. } \\
\hline 101. Koliella sp. & Dinophyceae \\
\hline 102. Oocystis borgii Snow & 141. Amphidinium acutum Loh. \\
\hline 103. O. solitaria Wittrock & 142. A. globosum Schroder \\
\hline 104. O. sp. & 143. Ceratium extensum (Gour.) $\mathrm{Cl}$. \\
\hline 105. Pandorina morum (O. Muller) Bory & 144. C. furea Her. \\
\hline 106. Pediastrum boryanum (Turp.) Menegh. & 145. C. gibberum Gour. \\
\hline 107. P. simplex (Meyen) Lemm. & 146. C. trichoceros (Ehr.) Koifoid \\
\hline 108. P. tetras (Ehr.) Ralfs. & 147. C. trupos var. pullchellum Shroder \\
\hline 109. Scenedesmus acuminatus (Lag.) Chodat & 148. Dinophysis caudata Saville-Kent \\
\hline 110. S. bijuga (Trup.) Lag. & 149. D. homunculus Stein \\
\hline 111. S. quadricauda (Trup.) De Breb. & 150. D. rudgei Murray \& Whiiting \\
\hline 112. Shroederia robusta Kors. & 151. Gymnodinium auratum Koifoid \\
\hline 113. Tetraedron minimum (A.Br) Han. & 152. G. mitratum Schil. \\
\hline \multirow[t]{2}{*}{ 114. T. trigonium (Naeg.) Han. } & 153. G. simplex Loh. \\
\hline & 154. Ornithocercus magnifcus Stein \\
\hline Chrysophyceae & 155. Oxytoxum variable Shil. \\
\hline \multirow[t]{2}{*}{ 115. Dictyocha trichantha Ehr. } & 156. O. sceptrum (Stein) Shroder \\
\hline & 157. Prorocentrum comprssum (Baily)ABFP\& DoDge \\
\hline Cryptophyceae & 158. P. dentatum Stein. \\
\hline \multirow[t]{2}{*}{ 116. Rhodomonas minuta var. nannoplanktonica Skuja. } & 159. P. gracile Shutt. \\
\hline & 160. P. micans Ehr. \\
\hline Cyanophyceae & 161. P. minimum (Pavillard) Schil. \\
\hline 117. Anabaena bergii f. minor (Kissel.) Ka. & 162. P. obtusidens Schil. \\
\hline 118. A. constica (Szalf) Geitler. & 163. P. triestinum Schil. \\
\hline 119. A. laxa (Rabench.) Born et Flah. & 164. $P . \mathrm{sp}$. \\
\hline 120. Anabaenopsis sp. & 165. Protoperidinium cerasus Paul. \\
\hline 121. A. sp. & 166. P. depressum Baily \\
\hline 122. Arthrospira jenneri Stizen ex. Gom. & 167. P. oblongum (Auriv.) \\
\hline 123. Chroococuus limneticus Lemm & 168. P. oceanicum Van. Hoffen \\
\hline 124. Coelospharium Kutzinginum Kütz. & 169. Pyrocystis lunula Schütt. \\
\hline \multicolumn{2}{|l|}{ 125. Cylindospermum majus (maius) Kütz. } \\
\hline 126. Merismopedia tenussisma Lemm. & Euglenophyceae \\
\hline 127. Microcytis elabens (Bréb.) Kütz. & 170. Euglena acus Ehr. \\
\hline 128. Nodularia sp. & 171. E. oxyhrius Schm. \\
\hline
\end{tabular}


Table 3. Distribution of phytoplankton species among the algal groups of Great Bitter Lake.

\begin{tabular}{|l|cc|}
\hline \multicolumn{1}{|c|}{ Groups } & No. of taxa & \% of the total number \\
\hline Bacillariophyceae & 88 & 51.46 \\
Dinophyceae & 29 & 16.96 \\
Chlorophyceae & 26 & 15.20 \\
Cyanophyceae & 24 & 14.04 \\
Euglenophyceae & 2 & 1.17 \\
Crysophyceae & 1 & 0.58 \\
Crysophyceae & 1 & 0.58 \\
\hline Total & 171 & 100 \\
\hline
\end{tabular}

Cyanophyceae constituted the second important group in terms of cell numbers, being dominant in autumn $(21.70 \%)$ and winter $(27.2 \%)$. Its high regional occurrence observed at the outlet of E.P.P. and III.VI stations during the study period and coincided with relatively low N:P ratios (2.8-6.6). It was correlated more with low N:P ratio (Fig. 4). Confirming our results, Smith (1983) stated that Cyanophytes generally dominate in conditions of reduced N:P Ratio and Shapiro., (1990) stated that the lowering in N:P ratio reflects the trophic level that enough for these organisms.

Oscillatoria chalybea (Nert.) Gomont Phormidium sp. and Cylindospermum majus (majus) kutz. were the most dominant species. Phormidium sp. forming the blooming with $N$. pseudo delicatissima and were correlated more with high $\mathrm{PO}_{4}$ and low N:P ratio (Fig. 5).

The percentage contribution of Chlorophyceae to the total phytoplankton density fluctuated between $0.7 \%$ and $15.5 \%$. Its highest population density of $16810 \times 10^{3}$ cells $1-$ 1 observed in winter when $\mathrm{PO}_{4}-\mathrm{P}, \mathrm{NO}_{3}-\mathrm{N}$ and $\mathrm{NH}_{4}-\mathrm{N}$ were high while its lowest value registered in summer when salinity and water temperature were high (Fig. 2). Its high regional occurrence observed at station III \& IV where they receive organically polluted water from domestic sewage.

Conforming our result, its population density exhibited a high positive and significant correlation with Faecal coli form (Ashour et al., 2000). Scenedesmus quadricauda (Turp.) de Breb and Actinastrum hanzschii (Lagerh) were the most dominant species. Together, these formed $47 \%$ of the total Chlorophyceae cells in winter. They are known to be common in various conditions of sewage ponds, Gray (1989).

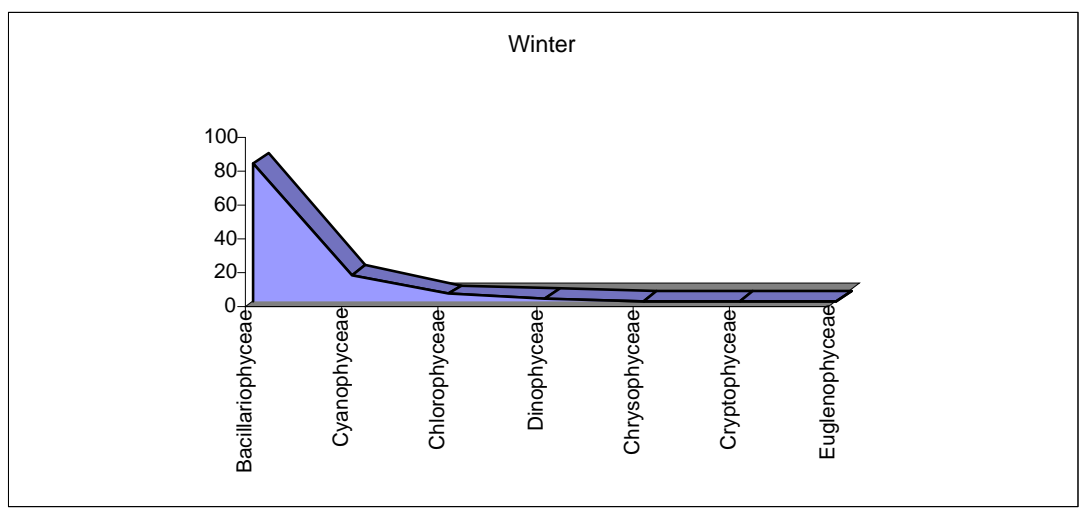

Figure 7. The seasonal variation of algal groups during the study period (1999-2000). 
Species composition and population density of phytoplankton of Great Bitter Lake, Suez Canal, Egypt.
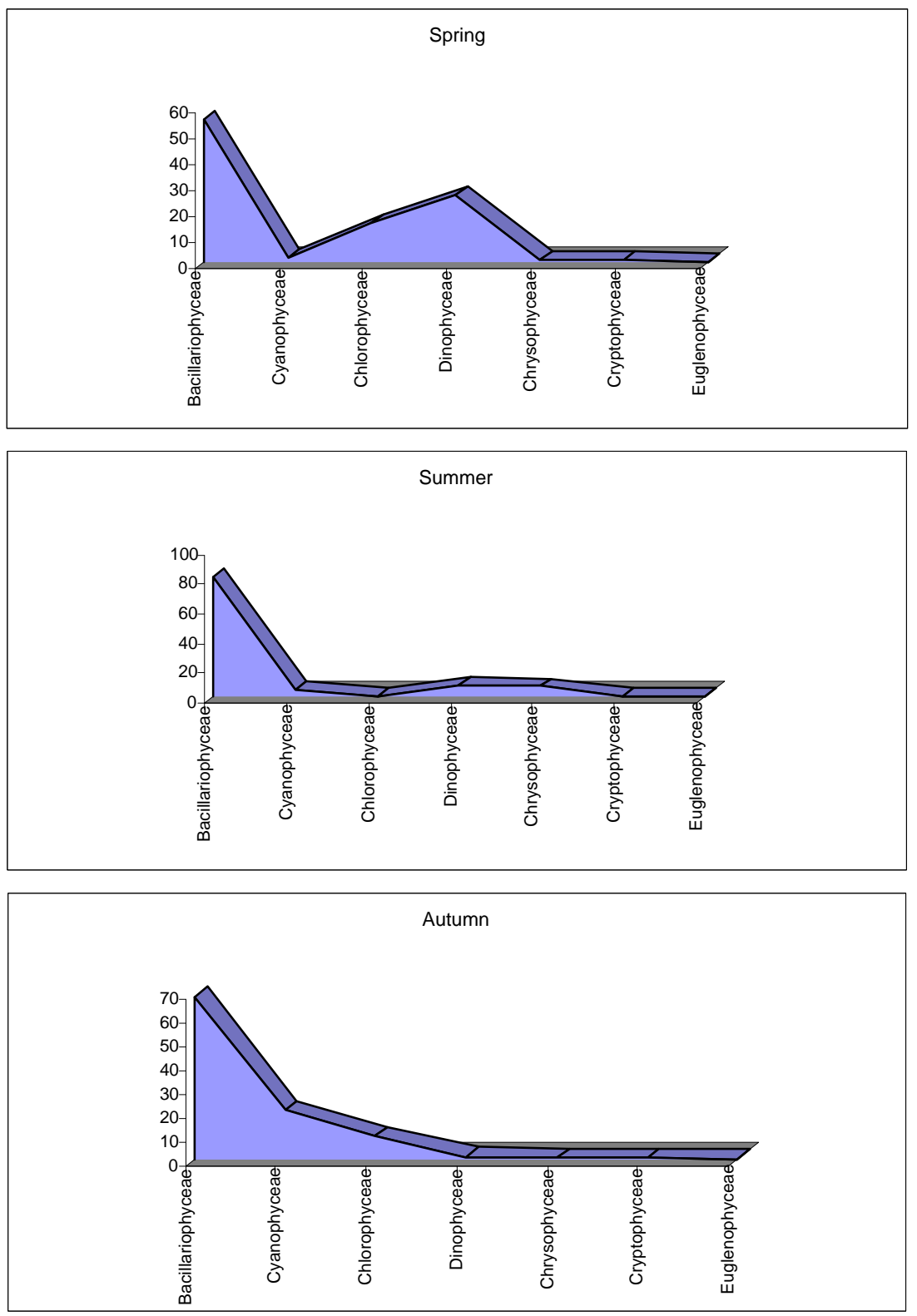

Figure 7. Continued. 
Dinophyceae increased during spring due to the luxuriance growth of Prorocentrum spp e.g. P. micans Ehr., P. dentatum Stein and P. minimum (Pav.) Sch. The mixture of their contribution abundance to the total Dinophyceae $(43 \%)$. Ceratium furca Ehr. was dominant throughout the study period but in few numbers. Protoperidinium oceanicum Van Hoffen showed an increase of $6450 \times 10^{3}$ cells $1^{-1}$ in summer when salinity, N:P ratio and temperature were high. Its regional occurrence was away from western side in connection of this Dinoflagellates are known for their euryhalinity (Smayda, 1983), and relatively high tamperature tolerances (Boney, 1975). Dinophyceae revealed a positive correlation with $\mathrm{NO}_{3}$, and $\mathrm{PO}_{4}$ and this finding disagree with Pollingher (1981); Pant et al; (1985) in that they are negatively correlated with SRP concentration.

Cryptophytes showed a seasonal variation. It was undetected in summer and winter seasons. Their absence during summer may be coincided with high numbers of ciliates and rotifers which are believed to apply high grazing pressure on small cryptophytes (Nauwerck, 1963); while in winter, their absence may be due to tremendous growth of other algal groups.

Confirming to this, Steward \& Wetzel (1986) stated that the decline of Cryptophytes coincided with population increase of other groups. Data indicate (Fig. 4) that Cryptophytes in Great Bitter Lakes were negativelly correlated with water temperature and salinity. Cryptophytes are known to develop substantially under low temperature and light conditions (Morgan and Kalff, 1979). It was represented only by Rhodomonas minuta var. planktonica Skuja.

Chrysophytes contributed all the investigation period except in winter and this counteract the opnion of Steward \& Wetzel, (1986) that this group seems to be relatively common in temperate lakes in winter. They were represented only by Dictyocha trichantha Ehr. It revealed a positive correlation with salinity and water temperature and negatively correlated with $\mathrm{PO}_{4}-\mathrm{P}$.

This finding is in agreement with several studies in which a negative correlation between $\mathrm{PO}_{4}-\mathrm{P}$ and the abundance of Chrysophytes existed (Eloranta, 1986, Sand Gren, 1986 \& Siver, 1995).

Euglenophyceae were represented by two species: E. oxyhrius Schm. and E. acus Ehr. Its contribution to the total crop was very small as compared to the above-mentioned groups. They are positively correlated with $\mathrm{Po} 4 \& \mathrm{NO}_{3}$ levels and low salinity. Its higher occurrence recorded in polluted water near the drain.

Species richness varied between 2 at Station 1 in winter and 55 at Stn. IV in spring, while the mean values of species diversity index (Shannon \& Wiener; 1963) ranged from 1.3 to 2.4 bits ind. $1^{-1}$. Generally, it was relatively low and this in accordance with Heimdal (1977).

The richness of the phytoplankton and the number of taxa of the various algal classes have been used often as an indicator for the trophic state of a lake. In eutrophic waters, a large number of Cyanophyta species is usually present, whereas in oligotrophic lakes, desmids and Chrysophytes dominate (Round, 1981; Eloranta, 1986). However, in Great Bitter Lakes, Chrysophytes and desmides were very low when compared to the other groups, especially Cyanophyceae. The seasonal average of the Trophic State Index, (Carlson, 1977), was between 47.7 and 50.3 indicating that the lake status lies between mesotrophic to moderately eutrophic condition. (Table 4). 
Species composition and population density of phytoplankton of Great Bitter Lake, Suez Canal, Egypt.

Table 4. Tropic Status index of Great Bitter Lake during the study period (1999-2000)

\begin{tabular}{|l|cccc|}
\hline & Spring & Summer & Autumn & Winter \\
\hline Input & 55.807 & 53.026 & 47.926 & 54.70 \\
Output & 39.558 & 51.448 & 46.591 & 48.72 \\
Palma Beach & 51.564 & 49.131 & 47.352 & 48.04 \\
Malaria & 50.336 & 46.743 & 56.685 & 51.60 \\
Main & 53.543 & 50.026 & 46.026 & 49.18 \\
Kabryet & 49.984 & 52.015 & 42.282 & 41.814 \\
\hline Min & 39.558 & 46.743 & 42.282 & 19.986 \\
Max & 55.807 & 53.026 & 56.685 & 62.264 \\
Average & 50.132 & 50.398 & 47.810 & 47.727 \\
\hline
\end{tabular}

\section{Conclusion}

The present investigation is essentially providing a base information concerning the population density and species composition of phytoplanktons in relation to the water quality of the Great Bitter Lake, mandatory for further limnological studies. In contrast to the unexploited eastern region, the western side of the lake has to be watched very carefully and frequently due to the over-exploitation of economic and tourism activities. Moreover, the study provides a sort of data-base necessary for water lake management and predictions for further evaluations of ecosystems.

\section{References}

Abdul-Hussein M. M. \& Mason. M, 1985. Zooplankton and phytoplankton interactions in a eutrophic reservoir. Ph.D. thesis, University of Essex.

APHA. 1992. Standard methods for the examination of water and wastewater $16^{\text {th }}$ edition. American Public Health Association.

Ashour M.S., Hewedy A.M., Ab dallah A.S., Gab Allah M.M. \& Toulibah E.H. 2000. The relationship between biotic and abiotic factors in the Great Bitter Lakes. $7^{\text {th }}$ International Conference, 8-11 Nov., 2000.

Boney, A. D. 1975. Studies in Biology no. 52 Phytoplankton. Edward Arnold. London 116 pp.

Carlson R.E. 1977. A trophic state index for the Lakes. Limnol. Oceanogy. 22(2):361-369.

Desikashary T.V. 1959. Cyanophyta. Indian Coun. Of Agric. Res. New Delhi. 686 pp.

Dowidar N.M. 1974. Distribution and ecology of Ceratium egyptiacum Halim and Validity as an indicator of the current regime in the Suez-Canal. J. Mar. Biol. Ass. India, 15(1):335-344.

Dowidar N.M. 1976. The phytoplankton of the Suez Canal. Acta Adriat., 18(14):241-255.

Eloranta P. 1986. The phytoplankton of some subarctic subalpine lakes in Finnish Lapland. Mem. SOC., Fauna Flora Fenn. 62:41-57.

El-Sherif Z. M. \& Ibrahim A. M. 1993. Phytoplankton production, diversity and chloroplyll a in the Suez Canal, Egypt. Bull. Nat. Inst. Oce. And Fish., A.R.E. 19: $119-144$.

Ezz-ElDin O. 1990. Some ecological studies on phytoplankton of Lake Bardawil. Ph.D Thesis, Zagazig Univ. Egypt 219 pp.

Gab-Allah M.M. 1985. Studies on the phytoplankton of Lake Timsah. M.Sc. Thesis, Bot. Dep. Fac. Of Sci., Suez Canal Univ. 
Gab-Allah, M.M. 1991. Some Ecological studies on the phytoplankton of Manzalah Lake. Ph.D Thesis, Bot. Dep. Fac. Of Sci., Suez Canal Univ.

Ghazzawi F.M. 1939. Plankton of the Egyptian waters. A study the Suez Canal plankton. (A) The phytoplankton. Notes Mem. Fish. Res. Dir. Cairo, 1-83 (With 2 Figures).

Gray F.N. 1989. Biology of Waste water Treatment. Oxford University. Press, New York.

Greenwald G.M. \& Hurburt, M. 1993. Microcosm analysis of salinity effects on coastal lagoon plankton assemblages. Hydrobiologia, 267: 307-335.

Halim Y. 1963. Microplankton des eaux Egyptiennes. Le genre Ceratium schrank (Dinoflagellates). Rapp. P-V. Reun. Conm. Int. Explor. Scient. Mer. Medit., 17(2): 449-502.

Halim Y. 1965. Microplankton des eaux Egyptiennes. II. Chrysomonadines Ebrieiens et Dinoflagellates nouveaux ou d'interet biogeogeaphique. Rapp. P.V. Reun. Common. Int. Explor. Scient. Mer. Medit., 18(2): 373-379.

Halim Y. 1990. On the potential migration of Indo-Pacific plankton-through the Suez Canal. Bull. déinstitut oceanographique, Monaco, 7:11-27.

Heimdal B.R.; Taasen, J.P. \& Elbrachter M. 1977. Net phytoplankton of the Great Bitter Lake in the Suez Canal. Sarsia, 6375-83.

Hendy N.I. 1964. An Introductory account of the smaller algae of British Waters Part. V. Bacillariophyceae (Diatoms). Ministry of organic., Fisheries and Food, Fishery University Ser.

Hustedt F. 1930 - 1937. Die Kieslagen 7. In. Rabenhorst (ed.) Kryptogamen, Flora Von Deutschland, Osterreich und der Schweiz. Akademische Verlags Gesell. Schalf M.L.H Leipzig.

Kimor B. 1972. The Suez Canal as a link and a barrier in the migration of planktonic organisms. Israel J. Zool., 21: 391-403.

Knuuttila S., Pietilainin P.O. \& Kauppi L. 1994. Nutrients balance and phytoplankton dynamics in two agriculturally loaded shallow lakes.

Madkour F.F. 1989. Ecological studies on the phytoplankton of the Bitter Lakes. M.Sc. Thesis, Dep. Of Bot., Fac. Of Sci., Suez Canal Univ., Egypt, pp. 155.

Martin J. L., Haya K., Burridge L. E. \& Wildish D. T. 1990: Nitzschia pseudo delicatissima Asource of domoic acid in the Bay of Funday, eastern Canada. Marine Ecology Progress series 67:177-182.

Miller, A. R., and Munns, R. G. 1974. The Bitter Lake salt barrier. In : l'ocanographic physique de la Mer Rouge. Symp. Assoc. Int. Sci: Ocean. CNEXO, Serie: actes coll. 2, $295-309$.

Mishara S. \& Panigrahy K.C. 1995. Occurrence of diatoms blooms in Bahuda estury, east coast of India. Indian Journal of Marine Science, 1995, 24(2): 99-101; 17 ref.

Morgan K.C. \& Kalff J. 1979. Effect of light and temperature interaction on growth of Cryptomonas erosa (Cryptophyceae). J. Phycol. 15: 127-134.

Nauwerck A. 1963. Die Bezie hunen Zwischen zooplankton and phytoplankton in Sea Erken Symbolae Botanicae. Up Salinoses. 17: 1-163.

Pant M.C., Jaio-wal S. \& Sharma A.P. 1985. A compositional and structure analysis of phytoplankton in Lake Khurpatal (U.P.), India , Imt. Revue ges. Hydrobiol. 70:269280.

Perscott A.G.W. 1978. How to know the fresh water algae (Third edition); 293 pp.

Pollingher U. 1981. The structure and the dynamic of phytoplankton assemblages in Lake Kinneret, Israel. J. Plankton Res. 3: 93-105.

Redfield A.C. 1958. The biological control of chemical factors in the environment. Am. Sci. 96: $205-210$. 
Species composition and population density of phytoplankton of Great Bitter Lake, Suez Canal, Egypt.

Reynold S.C.S. 1984. The ecology of fresh water phytoplan kton. Cambridge; University Press, $384 \mathrm{pp}$.

Round F.E. 1981. The ecology of algae. Cambridge University, Press, 653 pp.

Sand gren C. D. 1986. The ecology of chrysophyte flagellates; their grouth and perennation strategies as fresh water phytoplankton. Growth and survival strategies of fresh water phytoplankton (ed. C. D. Sandgren, pp. 9-104 Cambridge University press, Cambridge.

Shafik H.M., Gab-Alla M.M. \& Touliabah H.E. 1999. Phytoplankton and environmental factors of an economical important oligotrophic Lake, Lake Bardawil (North Sinai Egypt). 6th International Conference. 8-11 Nov. 99. 345-537.

Shannon, C. E. \& Weiner, 1963. A mathematical theory of communication. Urbana, Illinois University Press, 177 pp.

Shapiro J. 1990. Current belifs regarding dominance by Blue-Greens: The case for the importance for $\mathrm{CO} 2$ and $\mathrm{pH}$. Verh. Int. Ver. Limnol. 24: 38-54.

Siver P. A. 1995. The distribution of Chrysophytes along environmental gradients: their use as biological indicator. Chysophytes Algea: Ecology, Phylogeny and development (eds C. D. Sandgren, J. P. smal and J. Kristian sen), PP. 222-267 Cambridge University press, Cambridge.

Smayda T.J. 1983. The phytoplankton of estuaries. In B.H. Ketchum (ed.) Ecosystems of the world 26: Estuaries and Enclo. Sed. Seas. Elsevier Publ. New York:65-102.

Smith V.H. 1983. Low nitrogen to phosphorus ratios favor dominance by blue-green algae in lake phytoplankton. Science 221: 669-670.

Steward A.J. \& Wetzel R.G. 1986. Cryptophytes and other microflagellates as couplers in planktonic community dynamics. Arch. Hydrobiol. 106: 1-19.

Strickland J.D.H. \& Parsons T.R. 1963. A practical handbook of sea water analysis. Bull. Fish. Res. Bd. Can., 167:1-311.

Tilman D., Kiesling R., Strener R., Kilhom S. \& Johnson F.A. 1986. Green, Blue-Green and diatom algae: Taxonomic differences in Competitive ability for phosphorus, silicon and nitrogen. Arch Hydrobiol. 106: 473-485.

Tomas Carmelo R. 1997. Identifying Marine Phytoplankton. Academic Press. A division of Har Court Brac \& Company.

Van-Heurck H. 1986. Atreatise on Diatomaceae. William Wesley and Son, London.

Van Ipren J.M.1, Van Weering T.C.E. \& Van Brennekom A.J. 1987. Diatoms in surface sediments of the Indonesian Archipelago and their relation to hydrolography. Hydrobiologia 269/270: 113-128.

Wetzel R. G. 1983. Limnology. 2nd edn., Sanders College Publishing, 753 PP.

Willem E. 1991. Planktonic diatoms-an ecological review-Algological Studies 62 :69-106. 